\title{
PELATIHAN PENYUSUNAN MODUL AJAR BERBASIS ACTIVE LEARNING BAGI KELOMPOK GURU SMP TA’MIRUL ISLAM SURAKARTA
}

\author{
Anwari Adi Nugroho ${ }^{1}$, Nur Rokhimah Hanik ${ }^{2}$, Tri Wiharti ${ }^{3}$ \\ ${ }^{1,2,3}$ Program Studi Pendidikan Biologi, Fakultas Keguruan dan Ilmu Pendidikan \\ Universitas Veteran Bangun Nusantara Sukoharjo, \\ Email: bio_anwary@yahoo.com
}

\begin{abstract}
A team of biology education department Univet Bantara Sukoharjo has conducted active learning module training for teachers at Ta'mirul Islam Junior High School Surakarta. The purpose of the training was 1) To provide an understanding of the active learning-based modules 2) To provide training in developing active learning modules. The method used was lecture and question and answer, as well as guidance on the preparation of active learning based modules. Training activities begin with pretest and delivery of materials by seminar method (lecture). After the seminar, training was conducted with the module by the method. The teachers then went on to complete the live teacher learning module at home for two weeks. In the following week (2nd meeting) a review and guidance for improvement take 2.5 hours (150 minutes), and the activity ends with posttest. The learning outcomes show an average score. 27.22 of scale 100. The score indicates that the understanding of the learning module of the active learning module is still low and necessary. The average posted result is 86.11 (scale 100). The pretestpostest rate for each participant results in more than $25 \%$, which means that the increase from pretest to posttest meets the target. Training products assemble teaching modules as well. Obtaining a score of assessment of 4 teaching modules from teacher training result that is more than 70 (scale 100) which have fulfilled target minimum score 70 (scale 100).
\end{abstract}

Keywords: active learning, module, teachers

\begin{abstract}
Abstrak. Tim pengabdian kepada masyarakat prodi pendidikan biologi Univet Bantara Sukoharjo telah melaksanakan pelatihan penyusunan modul berbasis active learning bagi guru-guru di SMP Ta'mirul Islam Surakarta. Tujuan dari abdimas adalah 1) Untuk memberikan pemahaman tentang modul berbasis active learning dan 2) Untuk memberikan pelatihan dalam penyusunan modul berbasis active learning. Metode yang digunakan adalah ceramah dan tanya jawab, serta bimbingan praktek penyusunan modul berbasis active learning. Kegiatan pelatihan diawali dengan pretes dan penyampaian materi dengan metode seminar (ceramah). Setelah kegiatan seminar, dilaksanakan pelatihan penyusunan modul dengan metode workshop. Guru kemudian melanjutkan penyelesaian modul berbasis active learning guru di rumah selama 2 minggu. Pada minggu berikutnya (pertemuan PPM ke 2) dilakukan review dan bimbingan perbaikan selama 2,5 jam (150 menit) dan kegiatan diakhiri dengan posttest. Hasil pelatihan menunjukkan bahwa rata-rata skor pretes sebesar 27,22 dari skala 100. Skor tersebut menunjukkan pemahaman tentang penyusunan modul ajar berbasis active learning masih rendah dan perlu adanya pelatihan penyusunan modul ajar berbasis active learning. Hasil rata-rata postes yaitu sebesar 86,11 (skala 100). Sedangkan peningkatan skor pretes-postes setiap peserta diperoleh hasil lebih dari $25 \%$ yang berarti peningkatan dari pretes ke postes sudah memenuhi target. Produk pelatihan penyusunan modul ajar juga dinilai. Perolehan skor penilaian 4 modul ajar dari guru hasil pelatihan yaitu lebih dari 70 (skala 100) yang artinya sudah memenuhi target minimal skor 70 (skala 100).
\end{abstract}

Kata kunci : active learning, modul, kelompok guru

\section{PENDAHULUAN}

Pelaksanaan pendidikan yang bermutu tidak lepas dari peran dan tugas guru. Selama melaksanakan peran dan tugas sebagai seorang guru, tentu pernah menghadapi permasalahan dalam kegiatan pembelajaran di kelas. Permasalahan dapat berhubungan dengan proses maupun hasil belajar. Permasalahan pembelajaran bukan saja ada pada siswa, tetapi bisa juga berhubungan dengan fasilitas belajar, sistem evaluasi, guru, dan bahkan sekolah. Permasalahan guru banyak berkaitan dengan kompetensinya, sehingga guru dituntut meningkatkan kompetensinya agar menjadi guru profesional.

Guru profesional dituntut untuk selalu meningkatkan keprofesionalitasnya sehingga berdampak pada peningkatan kualitas 
pembelajaran. Peningkatan profesionalitas guru dapat dilakukan dengan cara mengembangkan buku ajar berupa modul. Modul adalah suatu proses pembelajaran mengenai suatu satuan bahasan tertentu yang disusun secara sistematis, operasional, dan terarah untuk digunakan oleh peserta didik, disertai dengan pedoman penggunaannya untuk para guru (Mulyasa, 2006). Kegiatan pembelajaran yang terdapat pada modul harus disesuaikan dengan karakteristik materi dan siswa sehingga dalam penerapannya dapat tujuan pembelajaran dapat tercapai.

Analisis kebutuhan melalui observasi buku ajar yang digunakan oleh guru - guru dalam pembelajaran menunjukkan bahwa dalam pembelajaran guru masih menggunakan buku teks yang didapat dari penerbit. Buku teks yang digunakan berisi cakupan materi secara luas dan umum, sehingga belum secara khusus berisi materi dan kegiatan pembelajaran yang sesuai dengan kebutuhan. Observasi juga dilakukan dengan wawancara terhadap kepala sekolah dan guru di Sekolah Menengah Pertama (SMP) Ta'mirul Islam Surakarta pada tanggal 5 April 2017 menunjukkan bahwa guru-guru memerlukan pembimbingan penyusunan modul ajar berbasis active learning (pembelajaran aktif). Guru di SMP Ta'mirul Islam berjumlah 28 dengan guru PNS sebanyak 10. Sementara jumlah guru di SMP Ta'mirul Islam Surakarta kebanyakan guru muda yang perlu pembimbingan penyusunan modul ajar.

Pembimbingan dari pusat atau dinas pendidikan masih kurang maksimal dan jarang dilaksanakan. Selama kurun waktu 3 tahun terakhir belum ada upaya dari sekolah untuk mencoba membimbing guru dalam menyusun modul ajar. Modul ajar berisi kegiatan pembelajaran yang disesuaikan dengan kebutuhan siswa dan karakteristik materi. Sesuai dengan Permendikbud No. 65 Tahun 2013 tentang Standar Nasional Pendidikan pada Standar Proses, bahwa pembelajaran dikembangkan dengan menekankan pada prinsip peserta didik untuk mencari tahu, menggunakan pendekatan ilmiah, mengembangkan kreatifitas, mengembangkan keterampilan aplikatif. Berdasarkan peraturan tersebut maka pembelajaran diharapkan dapat membuat siswa aktif (active learning) secara mandiri, kelompok maupun dengan pembimbingan guru. Hasil wawancara terhadap salah satu guru IPA di SMP Ta'mirul Islam menunjukkan bahwa pembelajaran masih dilakukan secara ekspositori dan belum mengarahkan pembelajaran aktif.

Akar permasalahan di mitra SMP Ta'mirul Islam adalah belum adanya pelatihan penyusunan modul ajar berbasis Active Learning. Sehingga solusi untuk mengatasi permasalahan tersebut adalah dengan pelatihan penyusunan modul ajar berbasis active learning. Modul ajar penting dalam pembelajaran karena pembelajaran dengan modul membuat siswa belajar secara mandiri, menemukan masalah yang berhubungan dengan pelajaran secara mandiri di lingkungan sekitar. Pembelajaran dengan modul juga memfasilitasi siswa untuk dapat belajar tidak terbatas oleh waktu, karena modul bersifat fleksibel dan dapat digunakan di luar kelas. Prastowo (2012) menjelaskan bahwa modul ajar berperan sebagai penghubung pengetahuan siswa dengan objek yang dipelajari dan memberikan kesempatan kepada siswa untuk menguasai satu unit materi pelajaran sebelum beralih ke unit berikutnya. Penelitian Musfiroh, Susantini, dan Kuswanti (2012) menyatakan bahwa pembelajaran menggunakan modul mendorong peserta didik untuk memahami materi, melatihkan peserta didik untuk melakukan pengamatan dan merumuskan pertanyaan penelitian. Pelatihan penyusunan modul ajar berbasis active learning bagi guru SMP Ta'mirul Islam Surakarta diharapkan guru-guru dapat terampil secara mandiri menyusun modul ajar berbasis active learning sesuai dengan bidang studinya, sehingga dapat meningkatkan profesionalisme guru dan berdampak pada meningkatnya kualitas proses dan hasil pembelajaran.

Berdasarkan latar belakang diatas maka diperlukan pelatihan penyusunan modul ajar berbasis active learning untuk meningkatkan kualitas proses dan hasil belajar, serta meningkatkan profesionalitas guru khusunya guru SMP Ta'mirul Islam. Pelatihan penyusunan modul ajar berbasis active learning untuk guru dilaksanakan oleh Tim Dosen Program Studi Pendidikan Biologi Universitas Veteran Bantara 
Sukoharjo dalam rangka pelaksanaan tugas Tri Dharta Perguruan Tinggi.

Target peserta adalah para guru SMP Ta'mitul Islam Surakarta yang berjumlah 9 orang. Sedangkan target kualitatif yaitu peserta memperoleh skor/ nilai rata-rata postes meningkat $25 \%$ dari nilai pretes dan memperoleh skor penilaian modul ajar berbasis active learning minimal 70 (skala 100) yang akhirnya dapat menghasilkan satu buah modul ajar berbasis active learning yang baik dan benar. Luaran dari pelatihan penyusunan modul ajar berbasis active learning adalah artikel ilmiah yang dipublikasikan di jurnal nasional ber-ISSN. Luaran lainnya adalah adanya modul ajar berbasis active learnin yang telah dibuat oleh guru setelah memperoleh pelatihan. Modul ajar berbasis active learnin dapat ditindak lanjuti oleh para guru secar mandiri untuk diimplementasikan pada pembelajaran, sebagai upaya memperbaiki kualitas pembelajaran.

\section{METODE PELAKSANAAN}

Pelatihan penyusunan modul ajar berbasis active learning bagi Guru SMP Ta'mirul Islam Surakarta dilaksanakan di SMP Ta'mirul Islam Surakarta yang beralamat di Jl Dr Wahidin nomor 5, Bumi Kidul, Laweyan, Solo. Pelaksanaan pelatihan selama 2 bulan yaitu bulan juli sampai Agustus 2017. Metode yang digunakan dalam pelatihan ini ada 2 macam yaitu : Seminar-workshop dan metode bimbingan teknis individu penyusunan modul ajar berbasis active learning.

Berikut bagan pelaksanaan pelatihan modul ajar berbasis active learning.

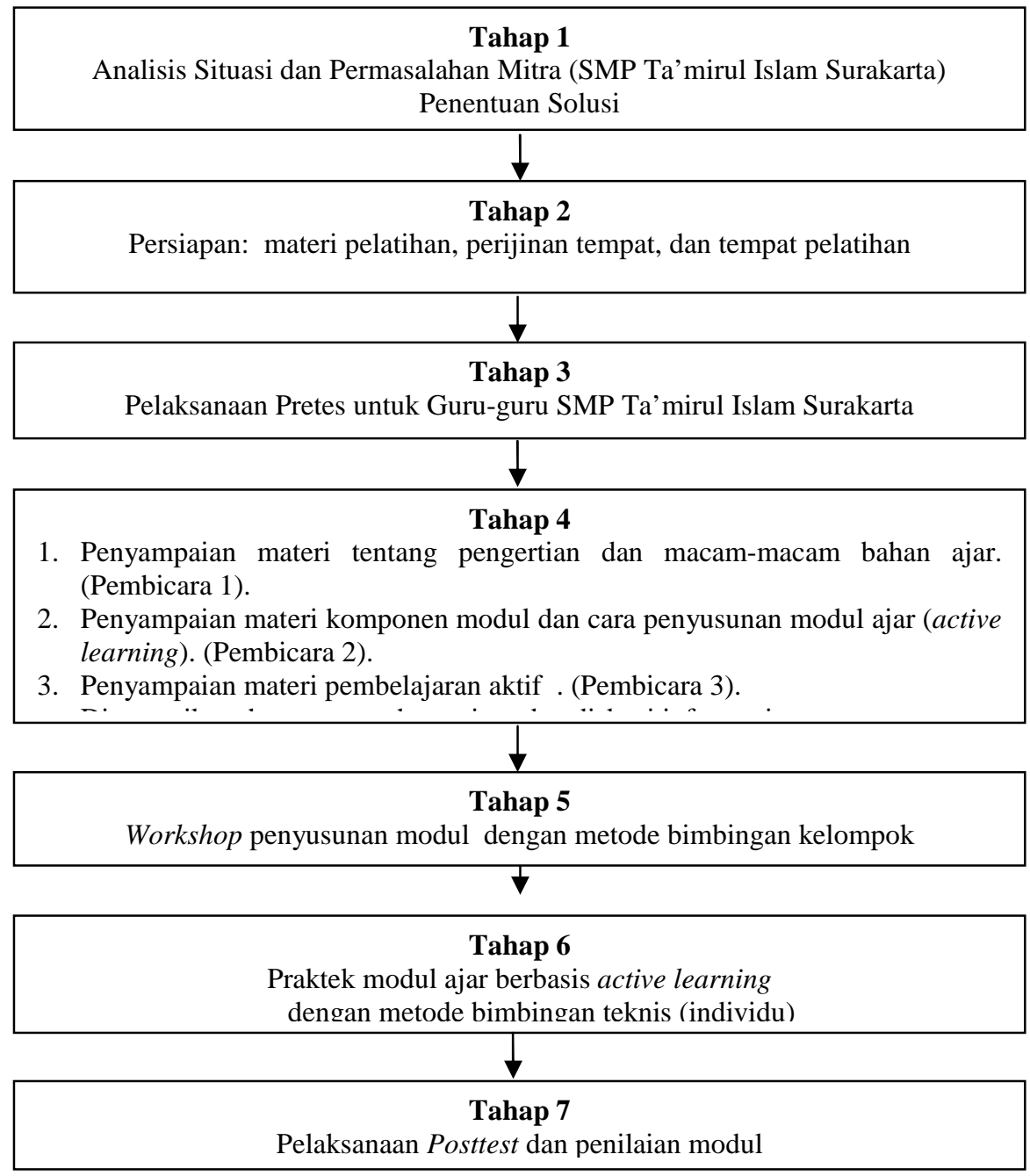

Gambar 1. Bagan Alir Pelaksanaan Pelatihan Modul Ajar.

Sistem evaluasi berupa pretest dan posttest untuk mengetahui kemampuan dasar dan peningkatan pengetahuan peserta terhadap materi dan praktek yang telah diberikan. Setiap jawaban diberi skor berdasarkan kriteria pemahaman dan ketrampilannya. 
Indikator keberhasilan program pengabdian adalah semua guru yang mengikuti pelatihan memiliki skor rata-rata posttest mengalami peningkatan dari skor pretest sebesar minimal $25 \%$.

Selain pretest dan posttest untuk melengkapi ada tidaknya peningkatan pemahaman para guru sebelum memperoleh pelatihan penyusunan modul ajar berbasis active learning dengan sesudah memperoleh pelatihan, juga dilakukan review / penilaian terhadap proposal yang dibuat para guru sesudah memperoleh pelatihan, dengan penyekoran sama seperti soal pretes dan postes setiap butir komponennya. Target skor penilaian modul ajar berbasis active learning minimal 70 (skala 100) setiap peserta.

\section{HASIL DAN PEMBAHASAN}

Pengabdian Pada Masyarakat dengan tema pelatihan penyusunan modul ajar berbasis active learning bagi kelompok guru SMP Ta'mirul Islam Surakarta telah dilaksanakan sampai pada tahap 7 yaitu tahap 1 kegiatan observasi sekolah, , tahap ke 2 kegiatan persiapan materi, tahap 3 kegiatan pemberian pretes, tahap 4 kegiatan seminar/ penyampaian materi, tahap 5 kegiatan workshop/ pelatihan tahap 6 kegiatan kegiatan pembimbingan teknis individu, tahap 7 kegiatan postes.

\section{Tahap 1}

Pelaksanaan kegiatan PPM dimulai dari observasi ke SMP Ta'mirul Islam Surakarta pada tanggal 3 Juli 2017. Kegiatan observasi dilakukana untuk mengetahui permasalahan pokok yang dihadapi guru. Observasi dilakukan dengan kegiatan wawancara terhadap kepala sekolah dan guru. Kegiatan observasi dilanjutkan pada tanggal 10 Juli 2017 dengan kegiatan menentukan tema PPM dengan kepala sekolah SMP Ta'mirul Islam Surakarta. Tema yang ditentukan yaitu tentang pelatihan penyusunan proposal PTK bagi guru-guru SMP Ta'mirul Islam Surakarta. Selain menentukan tema, tim
PPM dan sekoalh juga menentukan waktu dan tempat pelaksanaan kegiatan.

\section{Tahap 2}

Tahap kedua yaitu kegiatan persiapan meliputi penyiapan materi pelatihan; yaitu; pengertian dan macam-macam bahan ajar, komponen modul dan cara menyususnnya, macam-macam pembelajaran aktif. Materi tersebut dikemas dalam powerpoint dan handout sehingga praktis dan mudah dipahami oleh peserta. Soal pretes dan postes juga disusun untuk diujikan kepada peserta sebelum dan sesudah pelatihan. Persiapan lainnya adalah koordinasi dengan sekolah untuk menyiapkan tempat, alat dan bahan untuk pelatihan.

\section{Tahap 3}

Tahap ketiga kegiatan PPM pada tanggal 21 Juli 2017 adalah pemberian pretes tentang penyususnan modul ajar berbasis active learning kepada 9 guru SMP Ta'mirul Islam. Pretes dilakukan selama 60 menit untuk mengetahui kemampuan awal guru tentang modul ajar berbasis active learning sebelum menerima pelatihan. Soal pretes berbentuk pilihan ganda dengan jumlah 20 soal. Nilai/skor pretes digunakan sebagai patokan untuk menentukan keberhasilan pelatihan penyusunan modul ajar berbasis active learning.

\section{Tahap 4}

Tahap keempat kegiatan PPM pada tanggal 21 Juli 2017 (setelah pretes) yaitu kegiatan penyampaian materi penyusunan modul ajar berbasis active learning. Sebelum penyampaian materi didahului oleh pembukaan dari kepala sekolah SMP Ta'mirul Islam Surakartakemudian dilanjutkan dengan sambutan oleh ketua Tim PPM. Tim membagikan handout materi kepada peserta sebagai panduan dalam pelatihan. Jumlah peserta yang hadir dalam tahap ketiga ini yaitu 9 peserta guru SMP Ta'mirul Islam Surakarta (terlampir) 


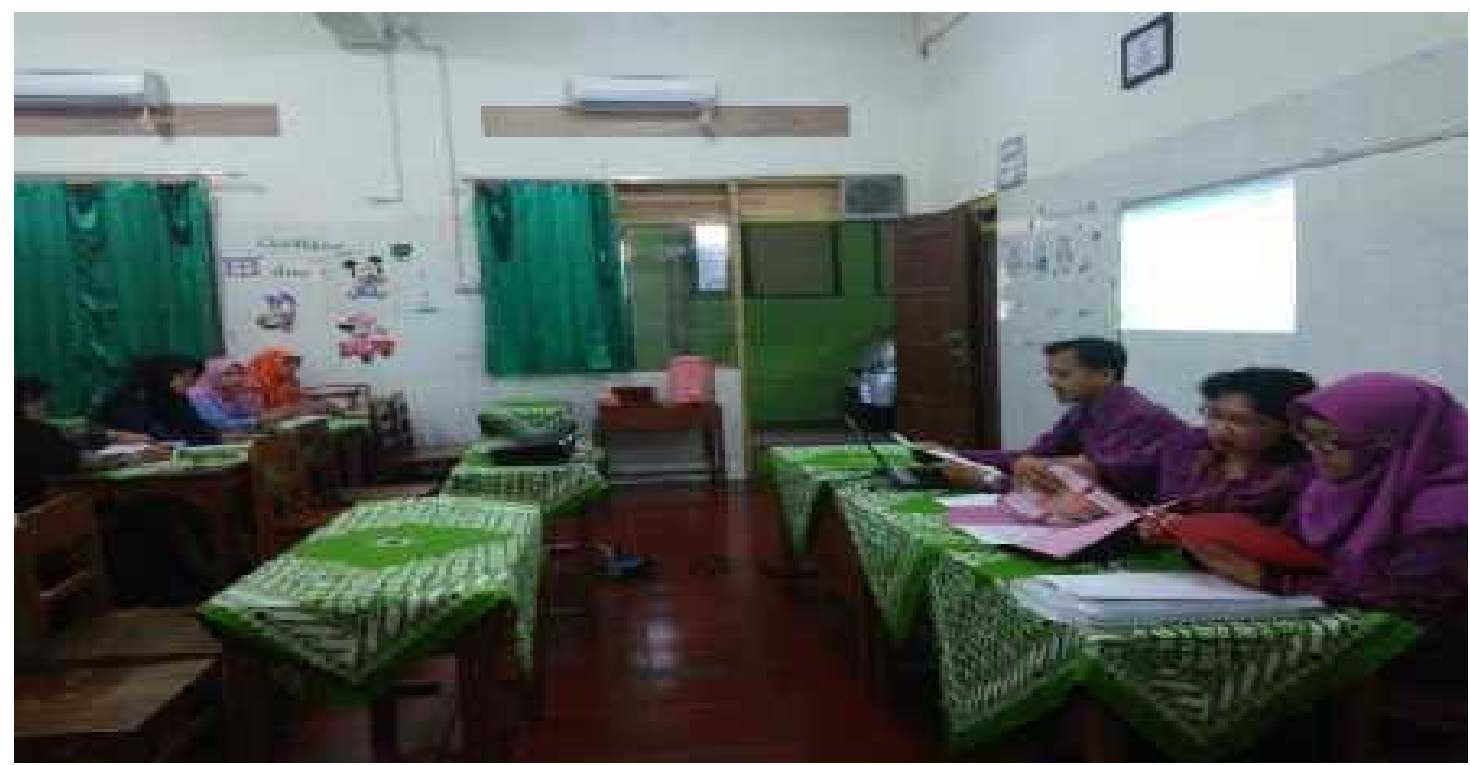

Gambar 2. Sambutan oleh Ketua Tim Pengabdian.

Penyampaian materi pertama yaitu oleh Dra. Tri Wiharti, M.Si dengan materi pengertian bahan ajar dan macam-macam bahan ajar. Penyampaian materi 1 dilaksanakan selama 45 menit dengan menggunakan powerpoint. Poin-poin materi pertama yang disampaikan antara lain Pengertian bahan ajar, bentuk-bentuk bahan ajar (bahan cetak, audio visual, audio, visual, multi media), cakupan bahan ajar (judul, mp, SK, KD, indikator, tempat; petunjuk belajar; tujuan yang akan dicapai; informasi pendukung; latihanlatihan; petunjuk kerja; penilaian), perbedaan buku ajar vs buku teks, jenis bahan ajar (worksheet, handout, buku ajar, leaflet, brosur, wallchart, modul, poster)

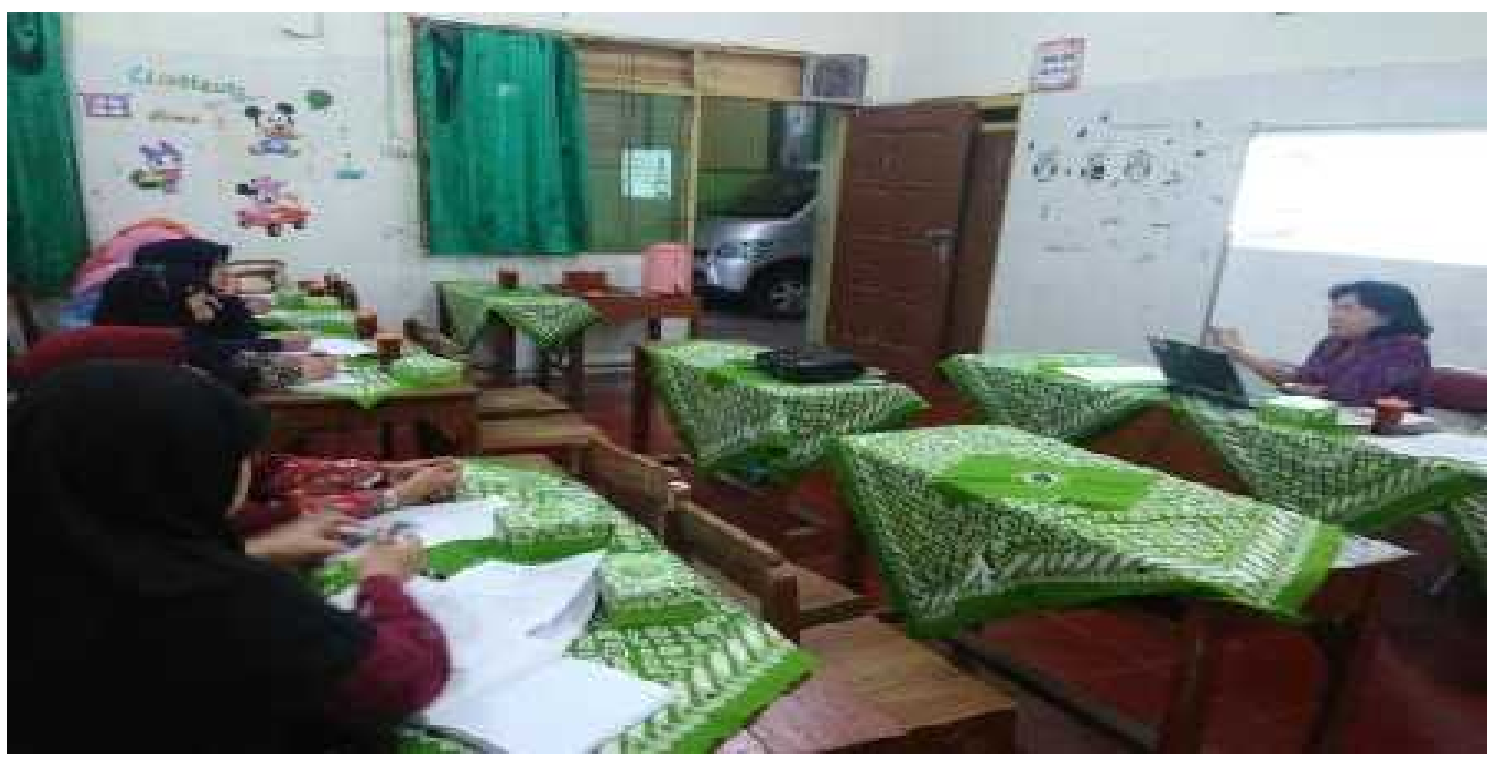

Gambar 3. Penyampaian materi 1 oleh Dra. Tri Wiharti, M.Si.

Setelah penyampaian materi 1 selesai, dilanjutkan penyampaian materi 2 oleh Anwari Adi Nugroho, S.Pd., M.Pd. tentang komponen modul dan cara menyusunnya. Penyampaian materi 2 dilaksanakan selama 45 menit dengan menggunakan powerpoint 


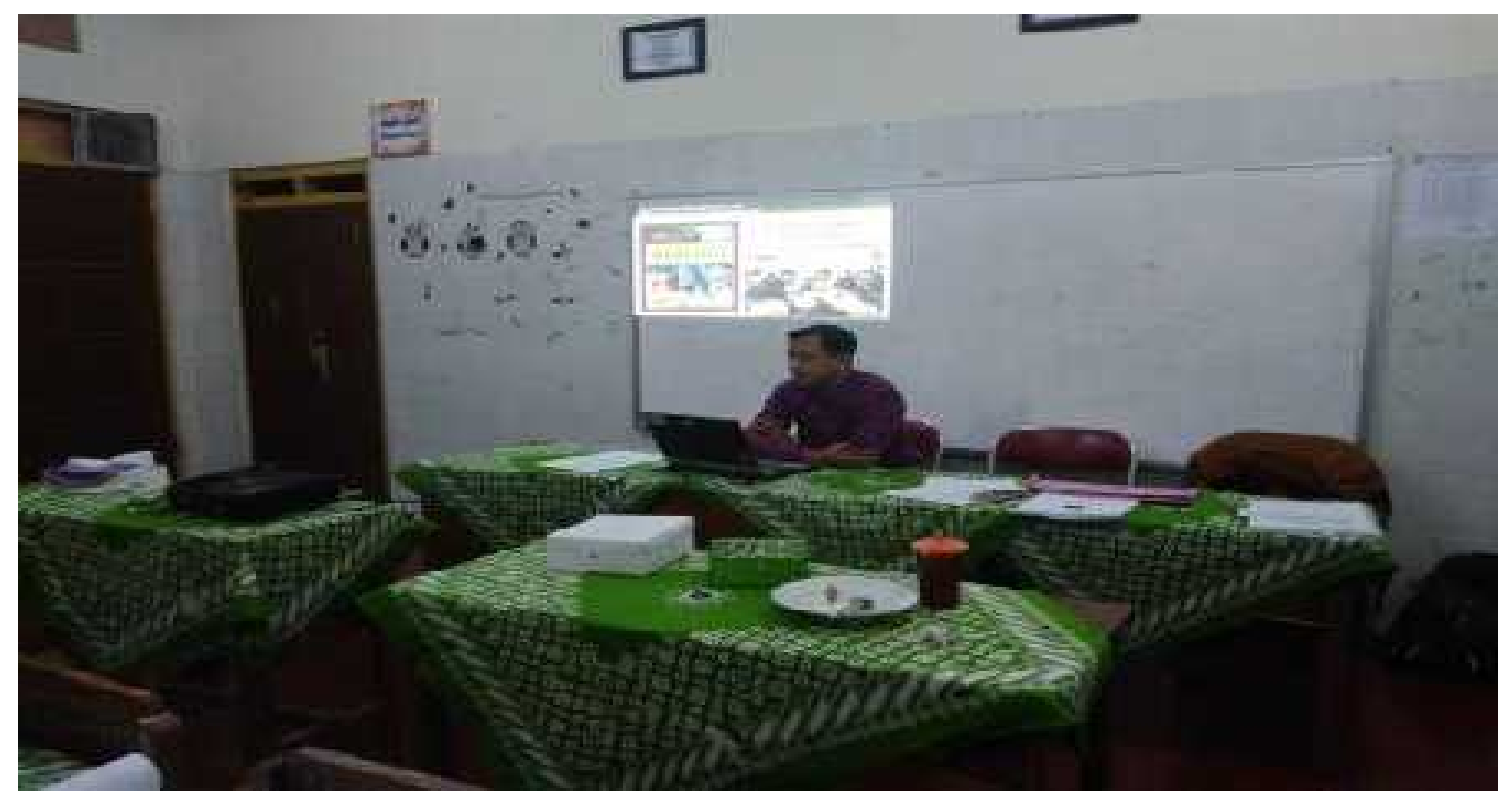

Gambar 4. Penyampaian materi 2 oleh Anwari Adi Nugroho, S.Pd., M.Pd.

Poin-poin materi kedua yang disampaikan antara lain pengertian dan tujuan modul ajar, karakteristik modul ajar (self instructional, self contained, stand alone, adaptif, user friendly), tiga tahapan pokok proses penyusunan modul ajar, hal-hal yang harus diperhatikan dalam penulisan modul (konsistensi, format, pengorganisasian, daya tarik, ruang), kerangka modul (halaman sampul, halaman francis, kata pengantar, daftar isi, peta kedudukan modul, glosarium, pendahuluan, pembelajaran, evaluasi), prosedur penyusunan modul (persiapan, penyusunan, validasi dan learning), model pembelajaran inkuiri.
Selanjutnya penyampaian materi 3 oleh Dra. Nur Rokhimah Hanik, M.P. tentang pembelajaran aktif. Penyampaian materi 3 dilaksanakan selama 45 menit dengan menggunakan powerpoint. Poin-poin materi ketiga yang disampaikan antara lain pengertian belajar, mengajar, dan pembelajaran, ciri model pembelajaran yang baik, perbedaan pendekatan, strategi, metode dan teknik pembelajaran, model pembelajaran kooperatif, model pembelajaran berbasis masalah (Problem Based Learning), model pembelajaran penemuan (discovery penyempurnaan).

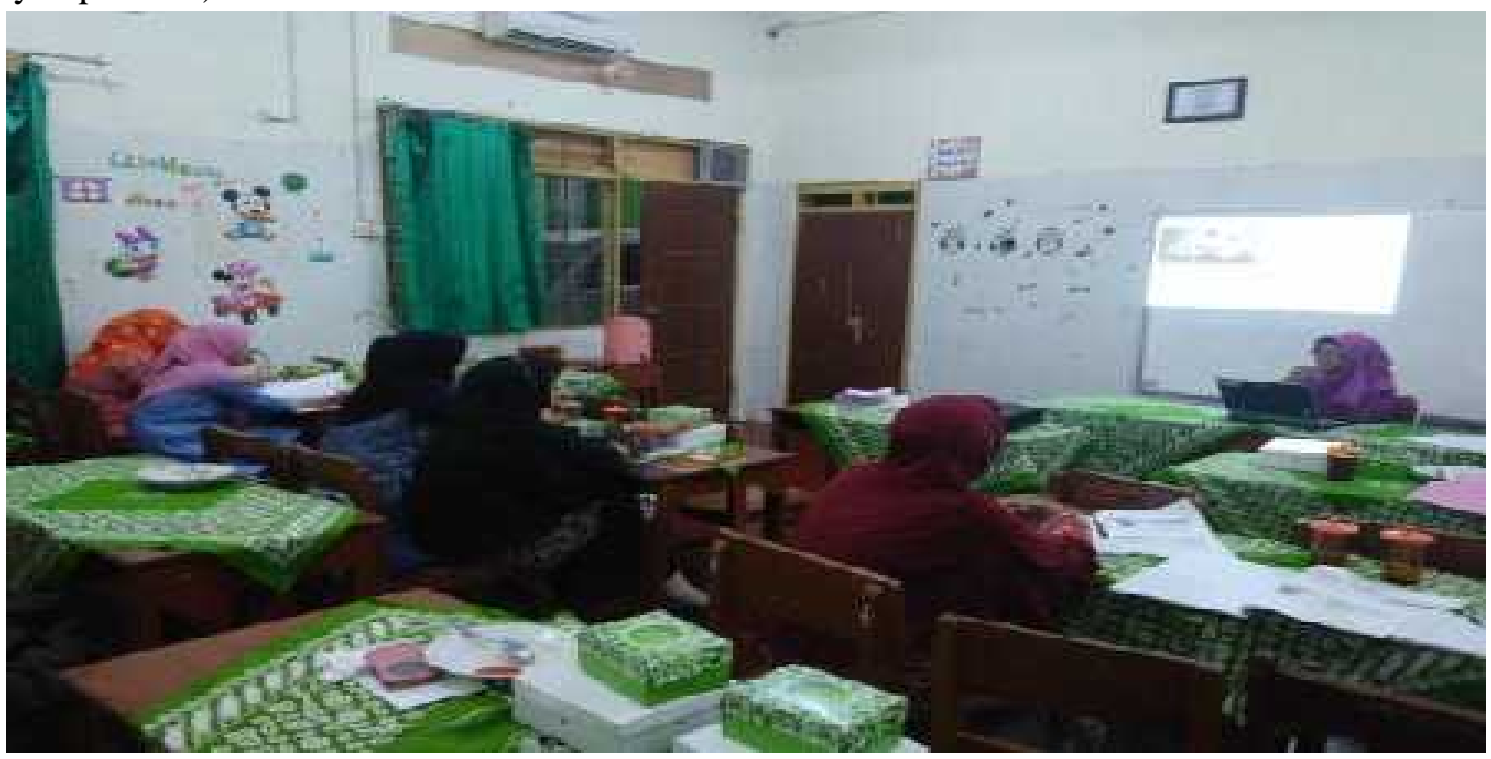

Gambar 5. Penyampaian materi 3 oleh Dra. Nur Rokhimah Hanik, M.P.

Setelah penyampaian materi selesai, Banyak peserta yang bertanya tentang modul dilanjutkan dengan kegiatan diskusi tanya jawab. ajar. Peserta yang sudah membawa modul ajar 
maupun drafnya, banyak yang tidak sesuai dengan kaidah/ aturan penyusunan modul ajar sehingga belum layak disebut sebagai modul ajar. Tim PPM menunjukkan contoh modul ajar yang sudah layak kepada peserta sebagai acuan dalam penyusunan modul ajar. Antusias dan semangat peserta cukup tinggi dibuktikan dengan banyak pertanyaan dari peserta.

\section{Tahap 5}

Tahap 5 adalah workshop/ bimbingan kelompok penyusunan modul ajar. Tahap ini merupakan kelanjutan dari kegiatan seminar/ penyampaian materi yang dilaksanakan dalam waktu sehari. Peserta dibagi menjadi 3 kelompok kemudian dilaksanakan pembimbingan terhadap draf modul yang sudah peserta buat. Draf modul kemudian dikoreksi oleh Tim dan diberi masukkan untuk diperbaiki. Beberapa peserta ada yang sudah membuat draf modul dan ada yang belum membuat draf modul. Kegiatan ini berlangsung selama 45 menit. Setelah kegiatan ini, peserta diberi waktu sampai dengan tanggal 25 Agustus 2017 untuk menyusun dan memperbaiki modul.

\section{Tahap 6}

Tahap keenam dilaksanakan pada tanggal 25 Agustus 2017 yaitu pembimbingan teknis individu penyusunan modul ajar berbasis active learning. Peserta yang sudah membuat draf modul sesuai dengan panduan kemudian arahkan untuk dapat mengimplementasikan modul tersebut dalam pembelajaran. Hanya ada 4 peserta yang membuat modul, sementara peserta lainnya masih dalam proses penyusunan.

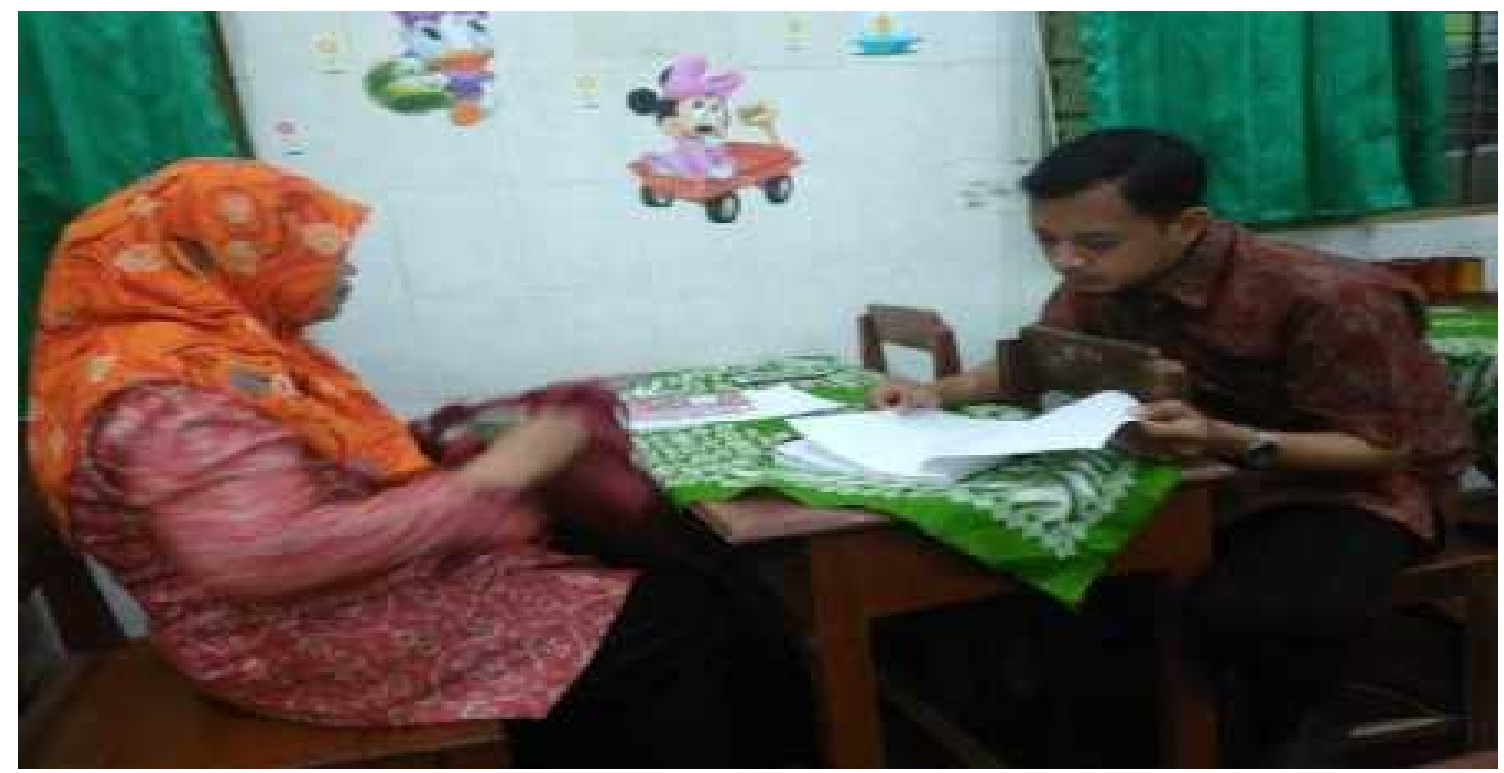

Gambar 6. Tahap Bimbingan Individu

Tahap 7

Tahap 7 dilaksanakan setelah tahap pembimbingan teknis individu. Kegiatan pada tahap ini adalah penilaian modul dari peserta dan postes. Modul ajar hasil karya peserta dinilai untuk mengetahui kelayakannya. Postes dilakukan selama 30 menit untuk mengetahui kemampuan akhir guru tentang modul ajar setelah menerima pelatihan. Nilai/skor postes digunakan sebagai patokan untuk menentukan keberhasilan pelatihan penyusunan modul ajar berbasis active learning.
Evaluasi pemahaman peserta tentang penyusunan modul ajar dilakukan dua kali, yaitu pretes dan postes. Nilai hasil pretes dan postes kemudian dibandingkan untuk mengetahui peningkatan pemahaman peserta sebelum memperoleh pelatihan dengan sesudah memperoleh pelatihan. 
Tabel 1. Hasil Penilaian Pretes dan Postes

\begin{tabular}{cccc}
\hline Peserta & Skor Pretes & Skor Postes & Peningkatan $(\%)$ \\
\hline 1 & 20 & 80 & 75,00 \\
2 & 15 & 85 & 82,35 \\
3 & 10 & 85 & 88,24 \\
4 & 25 & 90 & 72,22 \\
5 & 60 & 90 & 33,33 \\
6 & 40 & 85 & 52,94 \\
7 & 20 & 80 & 75,00 \\
8 & 20 & 80 & 75,00 \\
9 & 35 & 100 & 65,00 \\
\hline Jumlah & 245 & 775 & \\
\hline Rata-rata & 27,22 & 86,11 & \\
\hline
\end{tabular}

Berdasarkan Tabel 1 menunjukkan ratarata skor pretes sebesar 27,22 dari skala 100 . Skor tersebut menunjukkan pemahaman tentang penyusunan modul ajar berbasis active learning masih rendah dan perlu adanya pelatihan penyusunan modul ajar berbasis active learning. Setelah menerima pelatihan selama 2 pertemuan (seminar dan workshop, bimbingan teknis individu), guru-guru SMP Ta'mirul Islam Surakarta menghasilkan produk berupa modul ajar sesuai bidang studinya. Pada akhir pertemuan, dilaksanakan postes untuk mengukur kemampuan tentang menyusun modul ajar berbasis active learning. Hasil rata-rata postes yaitu sebesar 86,11 (skala 100). sedangkan peningkatan skor setiap peserta diperoleh hasil lebih dari $25 \%$ yang berarti peningkatan dari pretes ke postes sudah memenuhi target.

Produk pelatihan penyusunan modul ajar yaitu modul ajar berbasis active learning juga dinilai. Berdasarkan Tabel 7 diketahui 4 peserta dari 9 peserta telah jadi membuat modul ajar berbasis active learning. Perolehan skor penilaian modul ajar hasil pelatihan yaitu lebih dari 70 yang artinya sudah memenuhi target minimal skor 70 (skala 100).

Tabel 2. Hasil Penilaian Modul Ajar

\begin{tabular}{ccc}
\hline Peserta & Skor Penilaian Modul (skala 100) & Target Skor \\
\hline 1 & 80 & \\
2 & 85 & \\
3 & - & \\
4 & - & Minimal 70 \\
5 & 85 & (skala 100) \\
6 & - & \\
7 & 80 & \\
8 & - & \\
9 & - & \\
\hline Jumlah & 330 & \\
\hline Rata-rata & 82,50 & \\
\hline
\end{tabular}

Respon dan antusias peserta (guru) guru selama mengikuti pelatihan cukup tinggi, karena peserta sangat jarang memperoleh pelatihan sejenis. Sebelum mengakhiri pelatihan, tim PPM mengarahkan peserta yang telah membuat modul untuk diimplementasikan pada pembelajaran dan dapat menularkan ilmunya kepada guru-guru yang lain.

Modul ajar penting bagi guru dalam rangka untuk meningkatkan kualitas pembelajaran. Susilowati (2017), Rohmiyati, Ashadi, Utomo (2016), Nurjanah, Sajidan, Karyanto (2016), Habsari, Suciati, Maridi (2016) menyatakan bahwa pembelajaran dengan modul dapat meningkatkan hasil belajar siswa. Modul ajar yang dibuat oleh guru dan disesuaikan dengan kebutuhan siswa serta karakteristik materi akan lebih membuat pembelajaran lebih aktif dan siswa dalam belajar secara mandiri dengan modul.

\section{SIMPULAN DAN SARAN}

Pelatihan penyusunan modul ajar berbasis active learning pada kelompok guru SMP Ta'mirul Islam Surakarta dapat disimpulkan bahwa pelatihan penyusunan modul ajar berbasis 
active learning diperoleh hasil semua peserta ( 9 guru) memperoleh skor postes yang meningkat 25\% dari skor pretes. Modul ajar hasil karya peserta dinilai dan memperoleh skor $\geq 70$ (skala 100) yang artinya sudah mencapai target minimal skor penilaian modul ajar, sehingga modul alayak digunakan dalam pembelajaran.

Saran untuk pelaksanaan pelatihan modul sebaiknya pada tahap bimbingan individu lebih intensif dan dalam durasi yang lama sehingga semua peserta dapat menyususn modul. Pelatihan penyusunan modul ajar agar dapat dilanjutkan pada pendampingan implementasi modul sampai modul ajar dapat dinilai untuk kenaikan pangkat.

\section{UCAPAN TERIMAKASIH}

Tim pengabdian mengucapkan terimakasih kepada SMP Ta'mirul Islam Surakarta yang telah menjadi mitra pengabdian sehingga pelaksanaan pengabdian kepada masyarakat dapat berjalan dengan lancar dan tepat waktu. Tim pengabdian juga mengucapkan terimakasih kepada Universitas Veteran Bangun Nusantara Sukoharjo yang telah mendanai pelaksanaan Pengabdian Kepada Masyarakat Kompetitif Klaster (PMKK) tahun 2017.

\section{DAFTAR PUSTAKA}

Habsari, A.M., Suciati, Maridi. (2016). Pengembangan Modul Pembelajaran Biologi Berbasis Inkuiri Terbimbing disertai Interrelationship Diagram Pada Materi Pencemaran Lingkungan untuk
Memberdayakan Keterampilan Proses Sains dan Kemampuan Berpikir Interpretasi Siswa. Inkuiri: Jurnal Pendidikan IPA. Vol 5, No 3 .

Nurjanah, A.K., Sajidan, Karyanto, P. (2016). Pengembangan Modul Biologi Berbasis Model Guided Inquiry Laboratory Pada Materi Bioteknologi. Inkuiri: Jurnal Pendidikan IPA. Vol 5, No 3.

Mulyasa, E. (2006). Kurikulum Berbasis Kompetensi. Bandung : Rosda Karya.

Musfiroh, U., Susantini, E., dan Kuswanti, N. (2012). Pengembangan Modul Pembelajaran Berorientasi Guided Discovery pada Materi Sistem Peredaran Darah. Jurnal BioEdu Vol. 1/No. 2/Oktober 2012.

Prastowo, A. (2012).Panduan Kreatif MembuatBahan Ajar Inovatif. Yogyakarta: Diva Press.

Rohmiyati, N., Ashadi, Utomo, S.B. (2016). Pengembangan Modul Kimia Berbasis Inkuiri Terbimbing Pada Materi Reaksi Oksidasi - Reduksi. Jurnal Inovasi Pendidikan IPA. Vol 2, No 2.

Susilowati. (2017). Pengembangan Bahan Ajar IPA Terintegrasi Nilai Islam untuk Meningkatkan Sikap dan Prestasi Belajar IPA Siswa. Jurnal Inovasi Pendidikan IPA. Vol 3, No 1. 